\title{
Kwaliteit van de winst
}

\section{Bart Kamp}

SAMENVATTING In de financiële pers wordt tegenwoordig vaak gesproken over de 'kwaliteit van de winst'. Het begrip kwaliteit van de winst ${ }^{1}$ betreft niet zo zeer de bedrijfseconomische juistheid van de winstbepaling, maar heeft betrekking op de herkomst en stabiliteit van de winst. De kwaliteit van de winst heet hoog te zijn indien de winst afkomstig is uit de primaire activiteiten van de onderneming, goed voorspelbaar is, en in liquide vorm is gerealiseerd. Deze drie elementen lopen niet altijd parallel, waardoor het niet mogelijk is om de kwaliteit van de winst op een eenduidige manier te meten of te presenteren. De bestaande verslaggevingrichtlijnen geven verspreid over diverse onderdelen van de jaarrekening wel handvatten die bijdragen aan het inzicht in de kwaliteit. In de G4+1 Position Paper inzake het presenteren van de performance wordt met name het identificeren van de opbrengsten van de primaire activiteiten benadrukt. Al eerder zijn er in de praktijk methodieken ontwikkeld om de winst te schonen voor incidentele en 'niet-operationele' elementen in de winst. Een daarvan is het kengetal EBITDA. Dit cijfer is een benadering van de operationele resultaten die cash zijn ontvangen. Het belang van dergelijke aanvullende informatie wordt meer en meer door ondernemingen erkend. Dit blijkt uit het vrijwillig opnemen van dergelijke gegevens.

\section{Inleiding}

Onlangs heeft het Limperg Instituut een uitgebreid onderzoek afgerond omtrent de kwaliteit van de Nederlandse jaarverslaggeving (Hoogendoorn \&

Dr. B. Kamp RA is als universitair docent verbonden aan de Universiteit van Tilburg, en medewerker van BDO Accountants \& Adviseurs.
Mertens, 2001). Volgens dit onderzoek hangt de kwaliteit van de verslaggeving samen met de mate waarin belanghebbenden zich een goed oordeel kunnen vormen over de financiële resultaten en financiële positie van de onderneming: hoe beter dit oordeel mogelijk is, des te hoger is de kwaliteit van de verslaggeving. Met andere woorden, welke informatie hebben gebruikers van jaarrekeningen nodig om een oordeel te vormen, en in hoeverre verschaft de jaarrekening deze informatie?

Naast dit kwaliteitsbegrip van de jaarverslaggeving als geheel komen we tegenwoordig steeds vaker het begrip 'kwaliteit van de winst' (earnings quality) tegen. Kwaliteit van de winst is een begrip dat buiten het vakgebied van accounting is ontstaan, en voortkomt uit de praktijk van de financiële analyse. Wellicht mede hierdoor komt dit begrip nauwelijks aan de orde in de gangbare leerboeken op het gebied van externe verslaggeving (uitzonderingen zijn Penman, 2001, en Revsine et al., 2002). In de financiële pers wordt de kwaliteit van bedrijfswinsten echter regelmatig besproken, waarbij veranderingen in de kwaliteit van de winst implicaties kunnen hebben voor de beurskoers. Pas relatief recent komen de elementen van de kwaliteit van de winst naar voren in discussies over de presentatie van de financiële performance. Een prominent voorbeeld daarvan zijn de Position Papers van de G4+1 'Reporting Financial Performance' (1998 en 1999)2.

In dit artikel zal het begrip kwaliteit van de winst nader worden besproken, en worden gerelateerd aan de verslaggevingstandaarden en de praktijk van financieel-analisten. Een en ander wordt geïllustreerd met citaten uit Het Financieele Dagblad over 'kwaliteit van de winst'. In paragraaf 2 zullen de elementen van de kwaliteit van de winst worden besproken. In paragraaf 3 komt aan de orde in hoeverre deze kwaliteit meetbaar is. Vervolgens wordt in paragraaf 4 een overzicht gegeven van hoe de jaarrekening inzicht kan geven in de kwaliteit van de winst. Hierbij wordt een 
onderscheid gemaakt tussen voorschriften uit de regelgeving en kengetallen zoals die uit de praktijk van financieel-analisten voortkomen, zoals EBITDA en autonome groei.

\section{Accounting quality en earnings quality}

Het doel van de jaarrekening is om inzicht te geven in vermogen en resultaat. Veelal wordt verondersteld dat indien de jaarrekening is opgesteld conform de geldende standaarden (maatschappelijk aanvaardbare grondslagen), de jaarrekening hiermee automatisch aan dit doel voldoet. Het voldoen aan de (wettelijke) vereisten wordt wel angeduid als accounting quality. Worden de waarderingsgrondslagen juist toegepast, en geeft dit in samenhang met de presentatie en toelichting een realistisch beeld van de financiële positie? Accounting quality impliceert dus ook dat er geen sprake is van enige misleiding door creative accounting. Bij een voldoende accounting quality biedt de jaarrekening dus een juist inzicht in vermogen en resultaat. Daar waar Langendijk (1998) spreekt over 'kwaliteit van de winst' beperkt hij zich voornamelijk tot deze accounting quality.

De volgende stap in de financiële analyse is om een oordeel te vormen over (onder meer) het resultaat. Een van de aspecten die daarbij een rol speelt, is de kwaliteit van de winst. De kwaliteit van de winst behelst niet zo zeer de hoogte van de (netto)winst, maar meer de samenstelling en de wijze van berekening van de winst. Het doel van een (financiële) analyse van de jaarrekening is vaak om een voorspelling te doen over de toekomstige winstgevendheid van de onderneming. Dit geldt zowel voor beleggers voor wie het toekomstige rendement een bron van inkomsten is, als voor kredietverschaffers, zoals banken die voor de rentebetalingen en aflossingen eveneens afhankelijk zijn van een voldoende winstgevendheid van de gefinancierde onderneming. De essentie van het begrip kwaliteit van de winst is dat niet elke soort van inkomsten in dezelfde mate bijdraagt aan de verwachting van het toekomstige rendement. De 'hardheid' of 'vastheid' van de diverse soorten inkomsten kan verschillen. Het oordeel van gebruikers over de winststijging ten opzichte van het vorige jaar hangt daarom af van de kwaliteit van de winst. Een incidentele opbrengst of een grotendeels 'papieren winst' zal doorgaans minder worden beloond met een koersstijging dan hogere marges op de kernproducten.

In de spaarzame publicaties over kwaliteit van de winst worden verschillende kenmerken van de kwaliteit van de winst genoemd (Lev \& Thiagarajan, 1993; Schwartz \& Soo, 1996; Stickney \& Brown, 1999; Walton,
2000; White et al., 1997). Hierbij komen echter drie elementen vrijwel altijd terug. Er is sprake van een goede kwaliteit van de winst indien:

- de winst voortkomt uit de primaire activiteiten van de onderneming (de core business);

- de winst voorspelbaar is doordat de kosten en opbrengsten een stabiel karakter hebben;

- de winst gelijke tred houdt met de operationele kasstroom (liquiditeit van de winst).

Kwaliteit van de winst is dus een veelomvattend begrip. Het heeft zowel betrekking op de waarderelevantie van winstcijfers en stelselkeuzes, als op de voorspelbaarheid van winsten. Dit zijn de meest prominente onderwerpen van wetenschappelijk onderzoek op het gebied van verslaggeving. Bijgevolg is er dus per deelgebied zeer veel onderzoek verricht, maar het onderzoek naar de rol van het omvattende begrip als zodanig is zeer beperkt, althans veel minder dan dat het veelvuldig gebruik van dit begrip in de praktijk zou doen vermoeden. Lev \& Thiagarajan (1993) geven een overzicht van wetenschappelijk onderzoek op deze deelgebieden binnen het begrip kwaliteit van de winst.

\subsection{Winst uit het primaire proces}

De kracht van een onderneming zit in de specifieke positie, kennis of vaardigheden waarmee de onderneming zich onderscheidt van haar concurrenten. Hierin zit de meerwaarde van de onderneming die de toekomstige winstgevendheid moet waarborgen. Essentieel is dus dat de onderneming haar concurrentievoordelen ten volle benut. Inkomsten uit andere activiteiten kunnen weliswaar tot additionele inkomsten leiden, maar die vormen niet altijd een toegevoegde waarde bezien vanuit de belegger ${ }^{3}$. Denk hierbij aan inkomsten uit branchevreemde deelnemingen: een productieonderneming in een cyclische markt zou haar nettowinst kunnen stabiliseren door bijvoorbeeld een belang te nemen in een verzekeringsmaatschappij. Door het gebrek aan onderlinge synergie heeft deze diversificatie voor beleggers weinig toegevoegde waarde, mede omdat zij zelf vrijwel kostenloos hun portefeuille kunnen spreiden. Het zou in het algemeen beter zijn indien ondernemingen zich met name richten op hun eigen sterke punten, en van deze activiteiten de toekomstige winstgevendheid waarborgen. Over KLM wordt bijvoorbeeld gezegd: 'De kwaliteit van de winst is sterk verbeterd. Het zijn niet de incidentele baten die het resultaat stuwen, maar de operaties ofwel het vliegen met toestellen met goedbetalende inhoud' ( $F D, 2 / 2 / 01)$. Met betrekking tot de Nederlandse Spoorwegen wordt benadrukt dat de posten buiten het bedrijfsresultaat minder bij- 
dragen aan de kwaliteit van de winst: 'Maar de kwaliteit van de winst verslechterde. De verbetering is niet de uitkomst van hogere opbrengsten maar in zijn geheel het gevolg van lagere financiële en buitengewone lasten' ( $F D, 22 / 3 / 97)$.

\subsection{Voorspelbaarheid van de winst door stabiliteit van kosten en opbrengsten}

Wanneer men de winst van een onderneming wil voorspellen, is het prettig wanneer er een zeker momentum in de activiteiten zit, een trendmatige beweging of 'persistentie' (Eeftink, 2000). Deze vastheid in de activiteiten zal voor een groot gedeelte samenhangen met de aard van de bedrijfstak. Denk bijvoorbeeld aan een uitgever van tijdschriften die via abonnementen worden verkocht. Naar verwachting zal een groot gedeelte van het abonnementenbestand langdurig leiden tot omzet. Ook bij bijvoorbeeld levensverzekeringen staat al min of meer vast dat de huidige polishouders in de toekomst premies blijven betalen. Door deze voorspelbaarheid zijn sommige verzekeraars in staat om op redelijk nauwkeurige wijze in het jaarverslag de contante waarde te vermelden van de toekomstige premies die besloten liggen in het polisbestand (embedded value). Bij banken zijn het de rente-inkomsten die voor stabiliteit zorgen: 'Wat Kalff behalve de regionaal-strategische overwegingen heel belangrijk vindt, is dat de bank de kwaliteit van de winst van ABN Amro verhoogt. Het fundament in de VS wordt sterker en de winstbijdrage van Standard Federal heeft een heel stabiel karakter. Het gaat immers om rentebaten, de meest stabiele bron van bancaire inkomsten' (FD, 23/11/96).

In andere branches kunnen de verkopen een veel grilliger patroon volgen. Denk bijvoorbeeld aan een bergingsbedrijf van zeeschepen. Veel van de opdrachten van zo'n bedrijf staan min of meer op zichzelf, en het is elk jaar weer afwachten hoeveel opdrachten zullen worden geworven. Een goed gevulde orderportefeuille op dit moment is bij een dergelijk bedrijf lang niet zo'n sterke indicatie voor de toekomstige winstgevendheid als een polis- of abonnementenbestand bij verzekeraars of uitgevers. Ook de mate van conjunctuurgevoeligheid speelt een rol: 'De expansie moet meer volume en meer winst opleveren, maar ook een betere kwaliteit van de winst, omdat DSM zich richt op groei in producten met hogere marges en in het segment fijnchemie dat snel groeit en minder afhankelijk is van economische cycli' ( $F D, 1 / 8 / 96)$.

\subsection{Liquiditeit van de winst}

De meest conservatieve benadering van winstbepaling is om winst pas te erkennen als de opbrengsten daad- werkelijk in cash zijn ontvangen. Zolang het geld nog niet in handen is, zou er nog van alles mis kunnen gaan, en ben je dus nog niet helemaal zeker van de opbrengst. Een debiteur zou bijvoorbeeld failliet kunnen gaan. Uiteindelijk gaat het om geld, en 'cash is king. Idealiter zou de winst in een bepaald jaar dan ook daadwerkelijk in dat jaar 'in de kassa' moeten zitten. Er is dan geen onzekerheid over de realiteit van de opbrengst.

In de praktijk wordt een dergelijke mate van voorzichtigheid echter als niet realistisch beschouwd. Indien naar redelijke maatstaven de opbrengst voldoende zeker is, wordt de winst genomen, vooruitlopend op de daadwerkelijke ontvangst van het geld. Denk bijvoorbeeld aan onderhanden werk, waarbij de winstneming plaatsvindt naarmate het project vordert. De mate waarin de opbrengstverantwoording vooruitloopt op de geldbeweging kan van geval tot geval verschillen, waarbij de 'betrouwbaarheid waarmee de omvang van de baten kan worden vastgesteld' (Stramien van de RJ) verschillend kan worden geïnterpreteerd. Bricker et al (1995) vonden in hun onderzoek onder financieel-analisten een associatie tussen hoge kwaliteit van de winst en de mate waarin de winst kan worden gestuurd, bijvoorbeeld door de subjectiviteit in het waarderen van voorzieningen: hierdoor kan de onderneming in goede jaren geld opzij zetten voor latere jaren waarin het minder goed gaat. In het 'goede' jaar is de winst door de onderschatting relatief hard, terwijl de voorspelbaarheid hoog is door de egalisatiemogelijkheid. Bricker illustreert dit echter alleen met voorbeelden van uitspraken van analisten over goede jaren. Waarschijnlijk zal deze winststuring in de slechtere jaren minder worden gewaardeerd door de gebruikers. Zoals dat bijvoorbeeld gold bij Nomura: 'Waarnemers zetten overigens vraagtekens bij de kwaliteit van de winst die Nomura nog kon laten zien over het afgelopen jaar. Er zouden boekhoudkundige verschuivingen hebben plaatsgehad in de vorm van een vrijval van reserves' (FD, 23/595).

\section{Het meten van de kwaliteit van de winst}

In zijn algemeenheid is een begrip als kwaliteit moeilijk te meten, en dat geldt dus ook voor de kwaliteit van de winst. De kwaliteit van de winst kent meerdere aspecten, zodat het totaaloordeel niet eenduidig te meten is. Lev \& Thiagarajan (1993) construeren voor hun statistisch onderzoek een 'fundamental score' die wordt geacht de kwaliteit van de winst te meten. Hierbij worden de diverse indicatoren vertaald in positieve en negatieve signalen en vervolgens geag- 
gregeerd. Deze score blijkt sterk samen te hangen met de aandelenkoersen, hetgeen suggereert dat de kwaliteit van de winst relevant is voor de koersvorming. Deze maatstaf wordt echter buiten academisch onderzoek niet of nauwelijks gebruikt.

Een beperking van een enkelvoudige maatstaf zoals die van Lev \& Thiagarajan is dat afhankelijk van de gebruiker van de jaarrekening het accent op de diverse aspecten anders kan liggen. Denkbaar is dat bijvoorbeeld banken met name kijken naar de liquiditeit van de winst: zolang de winst nog niet cash is ontvangen, zal de financiering van de activa zoals vorderingen moeten worden voortgezet. Een potentiële overnemende partij zal wellicht meer geïnteresseerd zijn in de winstgevendheid van de primaire activiteiten. Grondslagen voor de resultaatbepaling kunnen niet altijd gelijktijdig alle elementen van de kwaliteit van de winst dienen. Door kosten uit te smeren over de gebruiksduur, wordt enerzijds de winst meer voorspelbaar, maar wordt de aansluiting met de kasstromen juist minder. Dit maakt het voor regelgevers moeilijk om de verslaggevingstandaarden te optimaliseren ${ }^{4}$. De bedrijfseconomisch 'juiste' grondslag is niet per definitie de grondslag die analisten prefereren om de kwaliteit van de winst te beoordelen. Denk hierbij bijvoorbeeld ook aan fair value accounting voor financiële instrumenten. Theoretisch is waardering tegen reële waarde beter dan kostprijswaardering, maar financiële instellingen verzetten zich tegen deze grondslag, met name vanwege het destabiliserend effect hiervan op de getoonde winst.

In de praktijk wordt alleen het liquiditeitsaspect gemeten. Hiervoor wordt de ratio tussen operationele kasstroom en winst (earnings quality ratio) gebruikt. De normwaarde van deze ratio ligt bij 1, waarbij een waarde hoger dan 1 erop duidt dat zelfs meer is ontvangen dan de winst, zodat de onderneming 'aan de veilige kant' zit.

Soms wordt de kwaliteit van de winst afgemeten aan de effectieve belastingdruk. Hierbij duidt een hoge belastingdruk op een hoge kwaliteit: het is recht-toerecht-aan winst waarop fiscaal weinig valt af te dingen, en dus kennelijk 'echt' en liquide is: 'De verbeterde kwaliteit van de winst blijkt uit het feit dat er over het derde en vierde kwartaal weer belasting moet worden betaald' (FD 10/6/95). Later valt KLM juist door de belastingdruk door de mand: 'Voor de kwaliteit van de winst behoeft feitelijk slechts naar de belastingpost te worden gekeken. Die daalde van $f 43$ miljoen in het derde kwartaal vorig jaar naar $f 8$ miljoen dit jaar. KLM betaalt volgens de eigen toelichting weer vennootschapsbelasting over het volledige resultaat, zodat de werkelijke winst rond $f 23$ miljoen moet schommelen, tegen $f 130$ miljoen een jaar geleden. Die $f 23$ miljoen komt angstvallig dicht bij de nu gerapporteerde $f 110$ miljoen minus de herwaardering van $f 89$ miljoen op het belang in NWA' (FD, 31/196) Kennelijk bestond de winst dus grotendeels uit een herwaardering, in plaats van liquide bedrijfsinkomsten.

De kwaliteit van de winst wordt daarom veelal beoordeeld als verbeterd of verslechterd ten opzichte van het verleden, zonder dit kwantitatief uit te drukken. Ook vergelijkingen tussen ondernemingen kunnen alleen luiden in termen van beter of slechter, zonder daarbij een nauwkeurige score te geven. Een gebrek aan nauwkeurige meting doet echter niet af aan het belang dat de kwaliteit van de winst heeft op de oordeelsvorming rond de financiële prestatie van de onderneming. In zijn algemeenheid geldt dat ook nauwkeurig bepaalde financiële ratio's uiteindelijk slechts in kwalitatieve zin bijdragen aan de oordeelsvorming van gebruikers. Het besluit om al of niet te investeren of te financieren is niet slechts de uitkomst van een kwantitatieve berekening.

\section{Aanknopingspunten met de verslaggevingregels}

Het begrip kwaliteit van de winst is in de regelgeving rond de jaarrekening niet expliciet terug te vinden. Dit geldt zowel voor de Nederlandse wet en RJ, als bijvoorbeeld ook voor IAS en US-GAAP. Toch zijn de elementen van de kwaliteit van de winst wel terug te vinden in diverse voorschriften en uitgangspunten. Hier zien we een raakvlak met de kwaliteit van de verslaggeving, waaraan in de inleiding werd gerefereerd: om een goed oordeel te kunnen vormen over de kwaliteit van de winst, moet de verslaggeving ook voldoende kwaliteit hebben. Het jaarverslag dient voldoende de relevante informatie te verschaffen die nodig is om een oordeel te vormen over de kwaliteit van de winst. Door een transparante verslaggeving kan de opsteller van de jaarrekening bijdragen aan het inzicht in de kwaliteit van de winst. De kwaliteit van de winst zelf is slechts gedeeltelijk afhankelijk van het gekozen verslaggevingbeleid. Het criterium dat de winst afkomstig moet zijn uit het primaire proces is naar zijn aard niet zo zeer een verslaggevingskenmerk, maar meer een eigenschap van de bedrijfsvoering: welke activiteiten ontplooit de onderneming? Van de jaarrekening mag echter wel worden verwacht dat deze inzicht geeft in hoeverre de winst afkomstig is uit het primaire proces. De G4+1 Position Paper sluit aan op deze eis door aan te bevelen dat de winst wordt gerubriceerd naar drie categorieën: 
- de resultaten uit de operationele activiteiten;

- de resultaten uit financieringsactiviteiten en treasury;

- overige resultaten.

Aan de andere twee criteria van de kwaliteit van de winst kan op andere wijzen tegemoet worden gekomen. Voorzover er meerdere grondslagen voor een bepaalde transactie mogelijk zijn, is het bijvoorbeeld denkbaar dat de opsteller kiest voor die grondslag waarbij de winstneming zoveel mogelijk gelijkloopt met de inkomende kasstroom. Er bestaat echter nog geen wijze van rapporteren waarbij alledrie de aspecten van de kwaliteit van de winst worden geïntegreerd. Men zal steeds op verschillende plaatsen in de jaarrekening informatie moeten zoeken, die tezamen een beeld oproepen over de kwaliteit van de winst. In het vervolg van deze paragraaf worden enkele elementen uit de verslaggeving besproken die bijdragen aan het inzicht in de kwaliteit van de winst. Hierbij wordt een onderscheid gemaakt tussen elementen die voortvloeien uit de regelgeving, en elementen die buiten de regelgeving om in de praktijk zijn ontstaan.

Elementen uit de regelgeving zijn:

- buitengewone resultaten

- te beëindigen activiteiten

- het kasstroomoverzicht

- wettelijke reserves

Elementen uit de praktijk zijn:

- autonome groei

- EBITDA

- Ergebnis nach DVFA en Headline earnings

\subsection{Buitengewone resultaten}

Het onderscheid tussen bedrijfsresultaat en buitengewone resultaten refereert in zekere mate aan het criterium van het primaire proces als naar incidentele aard. De verkoop van een deelneming is incidenteel van aard, en de opbrengsten hiervan hangen niet samen met het primaire proces. Rubricering onder de buitengewone baten zou dus in dit geval het verschil met de continue primaire opbrengsten goed duidelijk maken. Toch is dit onderscheid niet bij alle types van buitengewone resultaten zuiver. Kosten van afvloeiingsregelingen in verband met een reorganisatie worden vaak als buitengewoon gepresenteerd, terwijl die kosten toch sterk samenhangen met het primaire proces, de kosten van arbeid.

Het begrip buitengewone resultaten zoals dat thans in de jaarrekening wordt gebruikt, is dus niet voldoende om de kwaliteit van de winst met betrekking tot zowel de aspecten van herkomst als de incidentele aard inzichtelijk te maken. De G4+1 Position Paper bevat een voorstel waarbij het begrip buitengewone resultaten sterk wordt ingeperkt. Slechts zeer exceptionele gevallen, zoals nationalisaties en de gevolgen van natuurrampen, zouden kwalificeren als lasten die buiten de normale bedrijfsvoering vallen. Overige bijzondere baten en lasten dienen binnen het bedrijfsresultaat afzonderlijk te worden vermeld of toegelicht. Inmiddels is deze afzonderlijke vermelding van bijzondere baten en lasten opgenomen in IAS 8 en ORL 270.4. Daarnaast zou buiten het bedrijfsresultaat een afzonderlijke rubriek 'overige resultaten' moeten worden toegevoegd, waarin zaken als valutaresultaten en her- en afwaarderingen van vaste activa worden opgenomen. Deze nieuwe benadering biedt meer ruimte om het onderscheid te tonen tussen incidentele en bestendige kosten en opbrengsten van de primaire activiteiten ${ }^{5}$.

\subsection{Te beëindigen activiteiten}

Naast de segmentatie naar productgroep en/of geografie wordt in veel landen ook verlangd dat de financiële gegevens zoals omzet, bedrijfsresultaat en activa van te beëindigen activiteiten (discontinuing operations) afzonderlijk worden gepresenteerd naast de voortgezette activiteiten. In Nederland is een en ander opgenomen in RJ 345, die sterk gebaseerd is op IAS 35 . Deze eis tot nadere toelichting is voornamelijk opgenomen om de gebruiker beter inzicht te geven in de resultaten van de voortgezette activiteiten. Dit sluit dus sterk aan bij het voorspelbaarheidsaspect van de winst.

\subsection{Het kasstroomoverzicht}

Zoals hiervoor al genoemd, is de ratio tussen operationele kasstroom en winst een van de weinige kwantitatieve uitdrukkingen voor de kwaliteit van de winst. Hoewel in Nederland het kasstroomoverzicht niet wettelijk is voorgeschreven, is op basis van de RJ Richtlijnen opname hiervan de laatste jaren sterk ingeburgerd. In de meeste gevallen wordt het kasstroomoverzicht opgesteld volgens de indirecte methode, waarbij uit de samenstelling van de operationele kasstroom de aansluiting met de winst blijkt. Zeker in jaarrekeningen van grotere ondernemingen is deze verhouding dus doorgaans wel te bepalen. De Richtlijnen benadrukken bovendien de aansluiting tussen operationele kasstroom en winst: hoewel er theoretisch een voorkeur is voor de directe methode van het opstellen van het kasstroomoverzicht, schrijven de Richtlijnen voor dat bij toepassing van de directe methode aanvullende informatie dient te worden verschaft om toch ook deze aansluiting te kunnen maken. Met het kasstroomoverzicht kan men dus inzicht krijgen in hoeverre de winst liquide is. 


\subsection{Wettelijke reserves}

De Nederlandse wetgever heeft voor een aantal gevallen onderkend dat niet elke waardestijging van activa zondermeer winst is. Soms mogen bepaalde waardestijgingen in het geheel niet tot de winst worden gerekend, zoals ongerealiseerde herwaarderingen, soms behoort de waardestijging wel tot de winst, maar wordt de uitkeerbaarheid van die winst beperkt door het verplicht vormen van een wettelijke reserve.

De stijging van de nettovermogenswaarde van een deelneming door het behalen van winst door die deelneming wordt enerzijds wel tot de winst van de deelnemende rechtspersoon gerekend (resultaat deelnemingen), maar zolang de deelnemende rechtspersoon ontvangst van deze winst niet op korte termijn kan bewerkstelligen, mag deze winst niet door de deelnemende rechtspersoon worden uitgekeerd. Met andere woorden, indien het resultaat op deelnemingen voor de deelnemende rechtspersoon niet voldoende liquide is, telt deze winst niet mee voor de winstverdeling.

\subsection{Autonome groei}

In de praktijk wordt bij de analyse van de herkomst van de omzet vaak het onderscheid gemaakt tussen autonome groei en geacquireerde groei. Autonome groei verwijst naar de omzet- of winsttoename van de bedrijfsonderdelen zoals die aan het begin van het boekjaar al aanwezig waren. Daartegenover staat de omzet- of winstgroei door consolidatie van in het boekjaar overgenomen bedrijven. Hoewel de theorie hierover niet eenduidig is, wordt aan autonome groei een hogere kwaliteit toegedicht dan aan geacquireerde omzet, bijvoorbeeld doordat het iets zegt over de kwaliteit van het primaire proces: 'De autonome omzetgroei over 1999 kwam daardoor uit op 6\%, tegen gemiddeld $10 \%$ over de voorgaande jaren. Dat kwam de kwaliteit van de winst ten goede: de operationele marge (bedrijfsresultaat percentage van de bruto-omzet) steeg van 3,6\% naar 4,1\% en kan zich daarmee meten met die van de goedlopende supermarkten' ( $F D$ over Sligro, 28/1/00).

Om bij een groeistrategie die is gebaseerd op overnames de historische groei te kunnen volhouden, zal de onderneming steeds weer nieuwe overnamekandidaten moeten kunnen vinden en kunnen financieren. Als dat niet lukt heeft de directie wat uit te leggen: 'Een winstgroei lager dan 15\% is inderdaad ongebruikelijk voor een concern als Reed Elsevier. U moet echter beseffen dat onze gebruikelijke winstgroei van $15 \%$ altijd voor $1 / 3$ deel was te danken aan overnames. Het afgelopen halfjaar deden wij geen overnames en behaalden wij een autonome winstgroei van $13 \%$ ' (FD, 9/9/96).
Een ander argument is dat bij overnames gedurende het boekjaar soms de omzet van het overgenomen bedrijf wordt geconsolideerd vanaf het begin van het boekjaar. Deze omzet is dus gedeeltelijk 'gekocht' en geen resultaat van de eigen primaire activiteiten van de (overnemende) onderneming.

Voor het begrip autonome groei geldt ongeveer hetzelfde als voor kwaliteit van de winst: in de praktijk van de financiële analyse wordt er regelmatig naar verwezen, maar het is niet of nauwelijks terug te vinden in de verslaggevingsstandaarden. Slechts de Britse Standard FRS 3 verlangt een afzonderlijke vermelding van resultaten van pas verworven deelnemingen. Vermelding van de autonome groei in het jaarverslag is dus voor de meeste ondernemingen op vrijwillige basis. In de praktijk wordt met name door beursgenoteerde onderneming de autonome omzetgroei vaak vermeld. Vermelding van de autonome winstgroei komt minder vaak voor. Deze vrijwillige informatieverschaffing duidt erop dat opstellers beseffen dat informatie over autonome groei relevant is voor gebruikers. Geïnspireerd op de Britse standard is in het G4+1 Position Paper de aanbeveling opgenomen om informatie omtrent de autonome groei te vermelden.

\subsection{EBITDA}

EBITDA staat voor 'Earnings Before Interest, Taxes, Depreciation, and Amortization'. Het is een performancemaatstaf die vooral de laatste jaren opgang heeft gemaakt in Nederland. Hierbij wordt het bedrijfsresultaat (EBIT) gecorrigeerd voor de veelal arbitrair gekozen afschrijvingsmethodes voor vaste activa en goodwill. EBITDA heeft twee raakvlakken met de kwaliteit van de winst. Ten eerste richt EBITDA zich op het bedrijfsresultaat. De financieringsverhouding (rentekosten) en belastingdruk worden als niet-primaire activiteiten buiten beschouwing gelaten. Ten tweede richt EBITDA zich op de liquiditeit van de winst door de belangrijkste non-cash elementen - afschrijvingen - eveneens buiten beschouwing te laten. EBITDA benadert zo de liquide winst uit de primaire activiteiten. De merites van EBITDA lijken zo met name te liggen op het gebied van het beoordelen van de kwaliteit van de winst. In de literatuur wordt (terecht) vaak gewezen op de theoretische beperkingen van EBITDA om de performance te meten (zie o.a. Haenen, 2002). Een positieve EBITDA is niet voldoende om op lange termijn rendabel te zijn. Ook de investeringen (in materiële vaste activa en overnames) moeten uiteindelijk toch worden terugverdiend. Door de afschrijvingen hierover buiten beeld te laten, is EBITDA te optimistisch als algemene prestatiemaatstaf. Dit argument geldt ech- 
ter niet voor het beoordelen van de kwaliteit van de winst. Immers, daarbij gaat het niet primair om de hoogte van de winst, maar om de samenstelling. De ontwikkeling van EBITDA gedurende de tijd geeft inzicht in de ontwikkeling van de primaire activiteiten. Wanneer we EBITDA vergelijken met de operationele kasstroom, zien we dat de operationele kasstroom de liquiditeit van de bedrijfsvoering nauwkeuriger meet. Er wordt niet alleen gecorrigeerd voor afschrijvingen, maar ook voor mutaties in de voorzieningen en afnemers- en leverancierskrediet. Daartegenover staat dat de operationele kasstroom veelal ook de voor de kwaliteit van de winst minder belangrijke financieringslasten en belastingen bevat. Evenals de operationele kasstroom biedt EBITDA niet expliciet inzicht in de voorspelbaarheid (i.c. vaste, terugkerende elementen) van de winst.

\subsection{Ergebnis nach DVFA en Headline earnings}

Uit het bovenstaande blijkt dat de jaarrekening vaak enige aanwijzingen geeft over de kwaliteit van de winst. Met deze informatie kunnen analisten de gepresenteerde winst normaliseren. In Duitsland heeft deze normalisatie een grote vlucht genomen. De Deutsche Vereinigung für Finanzanalyse und Asset Management (DVFA) heeft al sinds 1968 richtlijnen uitgegeven om de gepresenteerde winst per aandeel te herrekenen naar een meer uniforme basis. Deze genormaliseerde winst wordt angeduid als Ergebnis nach DVFA. Het doel hiervan is:

- een beter beeld te geven van de trend in winstgevendheid;

- een beter uitgangspunt te hebben om de toekomstige winst te schatten;

- een betere vergelijking van de bedrijfseconomische performance tussen ondernemingen mogelijk te maken, zowel tussen Duitse ondernemingen onderling als ten opzichte van internationale kapitaalmarkten.

Deze doelstellingen hebben dus duidelijk een raakvlak met het begrip kwaliteit van de winst. De gecorrigeerde winst geeft als het ware de 'ongoing earnings' weer ${ }^{6}$. Om een idee te geven van de aard van de correcties, is hieronder een aantal correcties in hoofdlijnen weergegeven:

- R\&D-kosten dienen direct ten laste van het resultaat te komen;

- goodwill direct afboeken van het eigen vermogen;

- het elimineren (buiten het resultaat houden) van:

- buitengewone resultaten;

- winsten op sale \& leaseback;

- afwaarderingen;

- mutaties herwaarderingsreserve;
- mutaties van voorzieningen;

- valutaresultaten.

De richtlijnen voor het bepalen van de Ergebnis nach DVFA wordt regelmatig geüpdatet, op grond van ontwikkelingen in verslaggevingstandaarden en nieuwe inzichten. De bovenstaande correcties illustreren dat het doel van de normalisatie niet is om een theoretisch juistere winst te bepalen, maar om incidentele posten zoveel mogelijk te elimineren. De Ergebnis nach DVFA is dan ook niet bedoeld als een alternatief voor de gepresenteerde winst, maar slechts als een aanvulling daarop.

Het rijtie van correcties zoals hierboven genoemd, maakt duidelijk dat in sommige gevallen de jaarrekening niet voldoende gegevens biedt om de correcties nauwkeurig te kunnen aanbrengen. Valutaresultaten worden bijvoorbeeld niet integraal afzonderlijk vermeld. De analist zal dus op bepaalde punten schattingen moeten maken. Dit leidt ertoe dat verschillende analisten tot verschillende uitkomsten komen. De DVFA-benadering heeft echter inmiddels een dermate prominente plaats op de Duitse kapitaalmarkt ingenomen, dat een aantal ondernemingen in het jaarverslag zelf al de Ergebnis nach DVFA opneemt. Wetenschappelijk onderzoek (Booth et al., 1997) heeft aangetoond dat deze DVFA-correcties inderdaad een significante toegevoegde waarde hebben om het toekomstig aandelenrendement te voorspellen (earnings response coefficient $)^{7}$.

In Groot-Brittannië is door het Institute of Investment Management and Research (IIMR) in 1993 een soortgelijk schema voor winstcorrectie ontwikkeld, genaamd Statement of Investment Practice No. 1 'The Definition of Headline Earnings. Het kengetal headline earnings heeft ongeveer dezelfde betekenis als Ergebnis nach DVFA, namelijk een benadering van de 'maintainable earnings capacity'. Het aantal correcties op de nettowinst is minder dan bij de Ergebnis nach DVFA: headline earnings omvatten het bedrijfsresultaat zonder de resultaten van verkoop van deelnemingen, en zonder her- en afwaarderingen (Lin \& Walker, 2000). Evenals in Duitsland wordt deze gecorrigeerde winst ook in Groot-Brittannië door een groot aantal beursgenoteerde bedrijven op vrijwillige basis opgenomen in het jaarverslag.

\section{Samenvatting}

Het begrip 'kwaliteit van de winst' heeft betrekking op de herkomst en stabiliteit van de winst. De kwaliteit van de winst heet hoog te zijn indien de winst afkomstig is uit de primaire activiteiten van de onder- 
neming, goed voorspelbaar is, en in liquide vorm is gerealiseerd. Deze drie elementen lopen niet altijd parallel, waardoor het niet mogelijk is om de kwaliteit van de winst op één eenduidige manier te meten of te presenteren. De bestaande verslaggevingstandaarden geven verspreid over diverse onderdelen van de jaarrekening wel handvatten die bijdragen aan het inzicht in de kwaliteit. Het afzonderlijk vermelden van buitengewone resultaten en de invloed van te beëindigen activiteiten dragen bij tot het inzicht in de wel-structurele inkomsten. In de G4+1 Position Paper inzake het presenteren van de performance wordt met name het identificeren van de opbrengsten van de primaire activiteiten benadrukt. Al eerder zijn er in de praktijk methodieken ontwikkeld om de winst te schonen voor incidentele en 'niet-operationele' elementen in de winst. Een daarvan is het kengetal EBITDA. Dit cijfer is een benadering van de operationele resultaten die cash zijn ontvangen. Hoewel het kasstroomoverzicht nauwkeuriger de liquiditeit weergeeft, spitst EBITDA zich nog sterker toe op de kernactiviteiten. Het belang van dergelijke aanvullende informatie wordt meer en meer door ondernemingen erkend. Dit blijkt uit het vrijwillig opnemen van dergelijke gegevens.

\section{Literatuur}

Barth, M.E., W.H. Beaver, W.R. Landsman, (2001), The relevance of the value relevance literature for financial accounting standard setting: another view, in: Journal of Accounting and Economics, vol. 31, nr. 1-3, pp. 77-104.

Black, E.L., T.A. Carnes, V.J. Vernon, (2000), The value relevance of multiple occurrences of nonrecurring Items, in: Review of Quantitative Finance and Accounting, vol. 15, nr. 4, pp. 391-411.

Booth, G., J. Broussard, O. Loistl, (1997), Earning and stock returns: Evidence from Germany, in: The European Accounting Review, vol. 6, nr. 4, pp. 589-603.

Bricker, R.,G. Previts, T. Robinson, S. Young, (1995), Financial analyst assessment of company earnings quality, in: Journal of Accounting, Auditing and Finance, vol. 10, nr. 3, pp. 541-554.

Cahan, S.F., S.M. Courtenay, P.L. Gronewoller, D.R. Upton, (2000), Value Relevance of Mandated Comprehensive Income Disclosures, in: Journal of Business Finance and Accounting, vol. 27, nr. 9/10, pp. 1273-1301.

Cormier, D., M. Magnan, D. Zeghal, (2001), Value-relevance of earnings, cash flows and value added: north american and european differences, in: Accountancy en Bedrijfskunde, vol. 26, p. 33.

Dechow, P.M., (1994), Accounting earnings and cash flows as measures of firm performance. The role of accounting accruals, in: Journal of Accounting and Economics, vol. 18, nr. 1, pp. 3-42.

Dhaliwal, D., K.R. Subramanyam, R. Trezevant, (1999), Is comprehensive income superior to net income as a measure of firm performance?, in: Journal of Accounting and Economics, vol. 26, nr. 1-3, pp. 43-67.

Eeftink, E., (2000), Comprehensive income, over de som der delen, oratie Vrije Universiteit Amsterdam.

G4+1 group of accounting standard setters, (1998), (Australian Accounting Standards Board, Canadian Accounting Standards Board, International Accounting Standards Committee, New Zealand Financial Reporting Standards Board, United Kingdom Accounting Standards Board, United States Financial Accounting Standards Board), L. Todd Johnson en Andrew Lennard (principal authors), Position paper: Reporting Financial Performance: Current Developments and Future Directions.

G4+1 group of accounting standard setters, (1999), (Australian Accounting Standards Board, Canadian Accounting Standards Board, International Accounting Standards Committee, New Zealand Financial Reporting Standards Board, United Kingdom Accounting Standards Board, United States Financial Accounting Standards Board), Kathryn Cearns (principal author), Discussion paper: Reporting Financial Performance: Proposals for Change.

Guenther, D.A., D. Young, (2000), The association between financial accounting measures and real economic activity: a multinational study, in: Journal of Accounting and Economics, vol. 29, nr. 1, pp. 53-72.

Haenen, H., (2002), Voorliefde voor EBITDA maakt blind, in: Het Financieele Dagblad, 4 april 2002.

Harris, T.S., M. Lang, Möller, H.P., (1994), The value relevance of German accounting measures: An empirical analysis, in: Journal of Accounting Research, vol. 32, nr. 2, pp. 187-209.

Holthausen, R.W., R.L. Watts, (2001), The relevance of the value-relevance 
literature for financial accounting standard setting, in: Journal of Accounting and Economics, vol. 31, nr. 1-3, pp. 3-75.

Hoogendoorn, M.N., G.M.H. Mertens, (2001), Kwaliteit van externe financiële verslaggeving in Nederland, Kluwer, Deventer.

Hung, M., (2000), Accounting standards and value relevance of financial statements: An international analysis, in: Journal of Accounting and Economics, vol. 30, nr. 3, pp. 401-420.

Langendijk, H.P.A.J., (1998), De kwaliteit van de winst, in: Tijdschrift Financieel Management, vol. 18, nr. 4, pp. 17-22.

Lev, B., S.R. Thiagarajan, (1993), Fundamental information analysis, in: Journal of Accounting Research, vol. 31, pp. 190-215.

Lin, S., M. Walker (2000), FRS3 earnings, headline earnings, and accounting-based valuation methods, in: Accounting and Business Research, vol. 30, pp. 299-306

Penman, S.H., (2001), Financial statement analysis \& security valuation, McGraw-Hill, Boston.

Revsine, L., D.W. Collins, W.B. Johnson, (2002), Financial Reporting \& Analysis, Prentice Hall, Upper Saddle River, NJ.

Schwartz, K.B., B.S. Soo, (1996), Accounting actions ....assessing the quality of earnings, in: The Journal of Lending \& Credit Risk Management vol. 78, nr. 8, pp. 39-46.

Stickney, C.P., P.R. Brown, (1999), Financial reporting and statement analysis, Dryden, Forth Worth.

Walton, P., (2000), Financial statement analysis, Business Press, London.

White, G.I., A.C. Sondhi, D. Fried, (1997), The analysis and use of financial statements, Wiley, New York.

\section{Noten}

1 Men zou ook kunnen spreken over de kwaliteit van het resultaat in plaats van de winst, aangezien het resultaat ook negatief kan zijn. Hier wordt echter uitgegaan van het meer gangbare begrip kwaliteit van de winst, mede omdat in verliessituaties de notie van kwaliteit van het verlies contra-intuïtief is.

2 Bij het vraagstuk over het presenteren van de ondernemingsprestatie hoort ook het begrip comprehensive income. De onderbouwing van dit meer academische begrip loopt veelal synchroon met die van de meer praktische invalshoek van kwaliteit van de winst. Zie voor een overzicht van de discussie rond comprehensive income de oratie van Eeftink (2000). In dit artikel wordt de praktijkgerichte insteek gevolgd.

3 Het verband tussen gepresenteerde winst en de onderliggende bedrijfsactiviteiten is onderzocht door Guenther \& Young (2000).

4 Deze problematiek wordt besproken door Holthausen \& Watts (2001), Barth et al. (2001) en Hung (2000).

5 Black et al. (2000) vonden inderdaad een negatieve invloed van incidentele posten op de waarde van de onderneming. Zij verklaren dit door de schijn van winststuring die hier vanuit gaat.

6 Onlangs heeft kredietbeoordelaar Standard \& Poor's een paper genaamd 'Measures of Corporate Earnings' gepubliceerd. Hierin wordt een vergelijkbaar begrip genaamd Core Earnings geïntroduceerd, zie www.standardandpoors.com

7 Ook andere prestatiemaatstaven zijn uitgebreid empirisch onderzocht op hun relevantie voor de aandelenkoersvorming. Daarbij wordt meestal de relatieve verklaringskracht ten opzichte van de 'reguliere' winst geschat. Enkele voorbeelden zijn Dechow (1994) en Cormier et al. (2001) (kasstromen), Dhaliwal et al. (1999) en Cahan et al. (2000) (comprehensive income) en Harris et al. (1994) (Ergebnis nach DVFA). 